San Antonio Review • San Antonio Review (Volume III | Summer 2020)

\title{
You Will Not
}

David A. Grenardo

Published on: May 20, 2020

DOI: $10.21428 / 9 b 43 c d 98.61799 f 9 f$

License: Creative Commons Attribution 4.0 International License (CC-BY 4.0). 
A guidance counselor, parent, or coach,

Each utters the same remark, "You will not."

People you believe are beyond reproach, saying to you, you haven't got a shot.

You will not pass the test or make the grade.

You will not perform when it truly counts.

You will not win the game when it is played.

You will not beat the pressure when it mounts.

You will not amount to anything great.

You will not reach your goals by any means.

You will not escape your pathetic fate.

You will not fulfill any of your dreams.

I try to avoid these words of defeat,

They reek of envy, deceit, and despair.

But when I use these words they can't be beat.

You should use them too if you truly care.

You will not commit the same mistake twice

or allow bullies to prey on the weak,

You will not be silenced for any price.

A voice for the voiceless must always speak.

You will not lose faith when the road gets tough as you prove doubters wrong by what you do.

You will not sink when the waters get rough

Because there are others counting on you.

You will not forget where you came from or those who opened doors to show you the light.

You will not forget what you were made for, And you will not ever give up the fight. 
David A. Grenardo is a professor of law at the St. Mary's University School of Law in San Antonio, Texas. He was a four-year letterman in football at Rice University and earned his J.D. from Duke Law School. 